\title{
REPORT ON THE SNOW SURVEY OF GREAT BRITAIN FOR THE SEASON I949-50
}

\author{
By E. L. Hawke and D. L. Champion
}

THE basic material for this report again comes in the main from an efficient and enthusiastic corps of volunteer observers. They provide the Society month by month from September to May with daily records of snowfall and of any snow cover within their range of vision at a network of stations satisfactorily representing most of Great Britain's diversified climatic regimes. An increase in the number of these collaborators from about 135 to 185 has been the means of adding substantially to the mass of relevant daţa received by the Society. About one-half of this welcome accession is due to the courtesy of the Elder Brethren of Trinity House who, with the co-operation of the masters of twenty-six lightships positioned in coastal waters, have enabled the authors of this report to include for the first time a brief account of the season's snowfall in some of the sea areas bordering on the British Isles.

As in previous years, important help with the Society's investigations has accrued from dayto-day records of the state of the ground at a large number of the official weather stations which furnish regular returns to the national meteorological service. We have also again to acknowledge valuable supplementary information that has come from mountaineers and other travellers in districts not within the mesh of the Society's observational network. To all contributing observers and reporters, as well as to Sir Nelson K. Johnson, Director of the Meteorological Office, Air Ministry, and his staff, by whose favour the above-mentioned state-of-ground data are supplied to us, the officers in charge of the Snow Survey tender their appreciative thanks.

E. L. H.

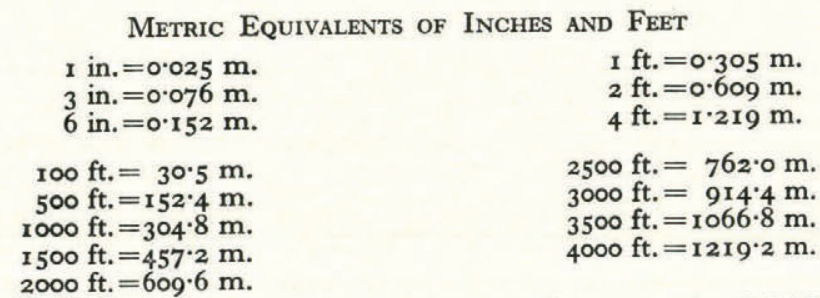

In general measurements of snow-depth cited in this Report refer to $\circ 9.00 \mathrm{hr}$. G.M.T., or thereabouts.

\section{SEPTEMBER 1949}

Over the whole of Great Britain this was a month of exceptional warmth for early autumn. In most districts the mean temperature exceeded the July normal, while at Oxford it was the highest registered for September in a record going back to 181 $_{5}$. No report of snowfall or snow cover was received from any station, even the highest of the Scottish mountains apparently being free-apart from such quasi-permanent accumulations as may have survived the hot summer in sheltered gullies.

\section{OCTOBER 1949}

The abnormal warmth of September persisted throughout the first half of October, and it was not until the 19th that the vanguard of winter began to invade the northern uplands of Britain. On this date an unstable maritime polar air-stream brought light snow to the Cairngorms and other Scottish heights above the $3000 \mathrm{ft}$. level. The first thin cover of the season at the summit of 
Ben Wyvis $(3429 \mathrm{ft}$.) was described by the observer at Fairburn as "most unusually late." During the next few days snowfalls gradually became more general on the mountains of Scotland and North Wales. By the 26th they had penetrated into England and Northern Ireland as cold northerly winds engulfed Britain in the wake of a deep cyclonic system which passed from the south coast of Ireland across the English midlands to Denmark. From the 27th to 30 th an inch or so of snow lay here and there at levels well below $1000 \mathrm{ft}$. north of a line from Cardiff to Skegness, even Wrexham (275 ft.), Denbighshire, having a thin cover for a short while early on the $27 \mathrm{th}$. Showers of snow extended on the 27th and 29th as far south as,Princetown (1359 ft.), Dartmoor.

With the advance of a high-pressure ridge from the Atlantic towards the close of the month there was a steady increase in the height of the snow line on Scottish mountains; between the 26 th and 30 th it rose from below $1000 \mathrm{ft}$. to above $3000 \mathrm{ft}$. on the Cairngorms.

\section{NOVEMBER 1949}

This was a mild and rather wet month. The occasional cold spells brought remarkably little snow to any part of Britain below the $1500 \mathrm{ft}$. level. Even Scottish stations at between $1000 \mathrm{ft}$. and $1200 \mathrm{ft}$. such as Dalwhinnie, Braes of Glen Livet and Braemar were entirely without cover-a rare occurrence there in November. The principal snowfalls were produced by an Atlantic depression which moved quickly from westward of Brittany to the French Riviera on the $6 t h-7 t h$. About this time various upland areas north of a line from the Bristol Channel to the Wash had a thin coating, the greatest depth reported being $2 \frac{1}{2}$ in. at Aberglanherin (1250 ft.), Radnorshire, on the morning of the 7 th. Further insignificant falls occurred later in the month, chiefly on the 13th-14th, 20th$22 n d$ and $28 t h-30 t h$. These were mostly confined to levels above rooo ft. In the southern half of England a few hill stations such as Craswall (rooo ft.), Herefordshire, and Princetown had one or two snow showers, but there appears to have been no cover anywhere in this part of the country.

\section{DECEMBER 1949}

Though mild on the whole in England and Wales, the last month of 1949 brought several periods of moderately severe weather to Scotland, and over the northern half of that country the mean temperature was appreciably below normal at many places. During the first week there was little snow except locally on the mountains, but on the 8 th a small polar-air disturbance formed off the Hebrides in a strong northerly wind-stream, and as this system moved south and later southeast across Britain one of the winter's most widespread series of snowfalls developed. From the 9 th to 12 th depths of 5 in. to 7 in. were common at moderate and low levels in Scotland, Wales and northern England. North and central Wales caught some of the heaviest storms. On the 9 th a cover averaging 14 in. deep was reported at Aberglanherin, Radnorshire; 12 in. of snow blocked parts of the road between Aberdovey and Dolgelly, while the Brecon mountains lay under Io in. at below $2000 \mathrm{ft}$. Llanfrothen ( $475 \mathrm{ft}$.), Merionethshire, had $8 \frac{1}{2}$ in. In Scotland, at Glen Ferness (700 ft.), Nairnshire, the average depth on the 10 th was 9 in.

Strong northerly winds caused drifting to $6 \mathrm{ft}$. or $7 \mathrm{ft}$. at some places on the Scottish mainland and also in the Isle of Harris. "Blizzard" conditions were said to have prevailed at Duntuilm, Isle of Skye, on the 9 th.

Snow showers penetrated as far south as Cornwall and Kent about this time. Princetown had a $\mathrm{I}$ in. cover on the 9 th and 10 th, increasing to 2 in. by the 12 th, but few other stations in southern England reported more than a sprinkling.

Although fairly widespread snow and sleet recurred over the northern half of Britain from time to time later in the month, especially between the 15 th and 20 th, there appear to have been no considerable falls at low or moderate levels. The period around Christmas was unseasonably mild throughout the country, and a rapid rise in the snow line resulted on some of the mountains. 
Ben More ( $3169 \mathrm{ft}$.), Argyllshire, was stated to be snow-free on Christmas Day and the Cuillins in Skye were bare on the 30tk and 31st. The Ben Wyvis group, however, had fresh snow to below $500 \mathrm{ft}$. on the $29 \mathrm{th}$ and $30 \mathrm{th}$. In Northern Ireland the topmost peaks of the Mourne Mountains (2796 ft.) lacked a cover after the 24 th.

At levels below rooo $\mathrm{ft}$. the maximum reported number of days with snow or sleet during December was 15 at Eskdalemuir (794 ft.), Dumfriess-shire, and Achnashellach (225 ft.), Ross and Cromarty. The maximum number of days with "snow lying" was io at Bellingham (849 ft.), Northumberland. Fairly numerous stations in the southernmost English and Welsh counties, as well as a few places on the Scottish coasts, came through the month without either snow or sleet.

JANUARY $195^{\circ}$

Dull anticyclonic conditions predominated. Over England and Wales as a whole precipitation amounted to only 54 per cent. of the average. In Scotland, however, the dryness was much less pronounced and at some stations in Banffshire and Caithness rainfall exceeded the normal by a substantial margin. The first half of the month was notably mild. Except in some of the mountainous districts of central and northern Scotland there appears to have been an almost complete absence of snow below the $1000 \mathrm{ft}$. line until the 16th. Even at rather higher levels appreciable falls were rare during this period, a cover of 3 in. to 4 in. at Wearhead (1 $100 \mathrm{ft}$.), Durham, on the 5th being exceptional.

Between the 16th and 18 th the region of maximum barometric pressure was transferred from south-westward to north-eastward of Britain, and for the remainder of the month north-easterly to essterly winds ruled with much colder weather. Yet there was little snow until after the close of the fourth week, mere powderings being observed even on the summits of Helvellyn ( $3 \mathrm{r} 88 \mathrm{ft}$.) and other mountains approximating to $3000 \mathrm{ft}$. in England and North Wales. This general immunity was due to a persistent anticyclonic wedge extending over the country from southern Scandinavia.

From the 29th to 31st, however, minor disturbances associated with a depression near Iceland brought a change to thoroughly unsettled conditions. Considerable snowfalls were widely distributed north of a line from Pembroke to Lowestoft. Average depths of 6 in. to 8 in. became common at moderate levels in northern England, while Cowpe Waterworks, Lancashire, at $1200 \mathrm{ft}$. reported a 12 in. cover on the $30 \mathrm{th}$. On the same day $8 \mathrm{in}$. of snow fell within three hours in parts of Lakeland. Drifts were $4 \mathrm{ft}$. deep at Malham Tarn (1297 ft.), Yorkshire (West Riding), and $4 \mathrm{ft}$. to $5 \mathrm{ft}$. deep at Cowpe Waterworks.

According to the Automobile Association more or less serious hindrance to road traffic occurred in seventeen counties on the 30th. In parts of the southern English midlands this was due to the incidience of wet sleet at a time when the surface air temperature stood several degrees below freezing point. On the ice-bound London road outside Luton, Bedfordshire, a traffic block extended for two miles at $10.30 \mathrm{hr}$.

Over Scotland generally the late-January snowfalls were of less intensity than in northern England, average depths of as much as $6 \mathrm{in}$. and drifting to more than $2 \mathrm{ft}$. being rare at moderate and low altitudes. Even at $700 \mathrm{ft}$. Glen Ferness had no measurable snow throughout the month. In Wales similar immunity was reported from medium-level stations such as Llanbadarn Fynydd ( $1350 \mathrm{ft}$.) and Aberglanherin, both in Radnorshire.

Though many of the higher Scottish ranges were under snow all through January, it was only on the 6 th and $30 t h-31 s t$ that the cover on them descended widely to below $500 \mathrm{ft}$. In Skye the Cuillins were bare during most of the month.

Entire freedom from January snow and sleet was common in South Wales and the southern counties of England. Very few stations in these parts of the country had more than a sprinkling on the ground at any time; a depth of $\mathrm{I}$ in. at Princetown on the 16 th was outstanding. 
At low and moderate levels the maximum reported number of days giving falls of snow or sleet was 7 at Dalwhinnie ( $176 \mathrm{ft}$.), Inverness-shire, and the maximum number of days with "snow lying" 6 at Midcalder (400 ft.), Mid Lothian, and Ushaw (594 ft.), Durham.

\section{FEBRUARY I950}

In contrast to January, this was a wet and stormy month-mild on the whole over England and Wales but rather cold over most of Scotland. At moderate and high levels snow was frequent and sometimes heavy, more particularly northward of a line joining Swansea and Flamborough Head. Until the 14th widespread falls occurred daily in the uplands of Scotland and northern England. On the Kilhope fell-tops at $2200 \mathrm{ft}$. in west Durham the resulting accumulation had reached a depth of 36 in. by the $13 t h$. Up to 24 in. was observed at $2800 \mathrm{ft}$. in the Cumbrian Hills on the $12 t h$, the snow there being heavily wind-crusted at some points. Undrifted depths of 5 in. to 8 in. at low levels and of $\mathrm{I} 2 \mathrm{in}$. or more at above $1000 \mathrm{ft}$. occurred commonly throughout the first fortnight of the month in Scotland, where the Perth-Inverness road and other highways became blocked at intervals.

During this period appreciable snowfalls were rare in the southern half of England, only a few hill stations reporting any cover. Craswall, Herefordshire, had $2 \mathrm{in}$. lying on the 6th and Exmoor 4 in. on the $9 t h$. In South Wales the upper reaches of the Brecon Beacons were under snow until the $13 t h$, and on the 6 th it lay 6 in. deep to below I $500 \mathrm{ft}$.

Mild weather ruled from the middle of the month until, on the $24 t h$ and $25 \mathrm{th}$, a depression off south-west Ireland moved south-eastward and then turned eastward across northern France, bringing cold north-east or east winds to most of Britain, with considerable amounts of snow in many northern areas and lighter though fairly widespread falls in the south. On the 25th a stretch of the road between Sheffield and Hathersage was covered to an average depth of ${ }_{15}$ in., while at Chew Mount ( $1600 \mathrm{ft}$.) Yorkshire, there were 30 in. drifts.

On the afternoon of the 26th the following series of observations was made on the southwestern slope of Pendle Hill ( $183 \mathrm{r} \mathrm{ft}$.) in the Central Pennines :

$\begin{array}{lllccccc} & & & 550 \mathrm{ft} . & 800 \mathrm{ft} . & 1200 \mathrm{ft} . & 1700 \mathrm{ft} . & \text { Summit } \\ \text { Average depth } & \ldots & \ldots & \text { patches } & \text { patches } & 6 \mathrm{in.} & 8 \mathrm{in} . & 6 \mathrm{in} . \\ \text { Drift depth } & \ldots & \ldots & 6 \mathrm{in} . & 2 \mathrm{ft} . & 3-4 \mathrm{ft} . & \mathrm{r} \mathrm{ft.} & \mathrm{Ift} .\end{array}$

Much of the snow which fell on the summit was blown off and deposited at levels several hundred feet lower down the hillside to leeward.

The Hoy Hills at ${ }_{1} 6_{5} \mathrm{ft}$. in the Orkney Islands were snow-topped on the northern side all through the month, the cover descending to sea-level from the 24th to 27th. Returns from Radnorshire show a curious anomaly. Whereas Aberglanherin at $1250 \mathrm{ft}$. lay under snow on 7 days in February, with an average depth of 4 in. on the $6 t h$, Llanbadarn Fynydd at $1350 \mathrm{ft}$. reported entire absence of either snow or sleet.

The maximum number of days with snow or sleet this month among the stations at low and moderate levels contributing to the Survey was 15 at Bwlchgwyn (1267 ft.), Denbighshire, and the maximum number of days with "snow lying" I5 at Balmoral (927 ft.), Aberdeenshire.

\section{MARCH I950}

March, a very mild and generally dry month, was notable for scarcity of snow throughout Great Britain. Such falls as did occur at moderate and low levels mostly took the form of light showers and were confined in the main to northern districts. Their maximum frequency (five days) was in the Orkney and Shetland Islands and on the Yorkshire moors. The Hoy Hills (Orkneys) 
had a coating to below $1500 \mathrm{ft}$. from the $10 \mathrm{th}$ to $17 \mathrm{th}$. Farther south cover was rare or absent even on some of the higher mountains: it was reported at the summit of Ben Cruachan ( $3689 \mathrm{ft}$.$) ,$ Argyllshire, only on the $1 s t$ and $2 n d$. On Ben More (3169 ft.), Isle of Mull, and Paps of Jura $(257 \mathrm{I} \mathrm{ft}$.) there was none at all. Cairngorm peaks at about $3500 \mathrm{ft}$. displayed mere patches of thawing snow for the greater part of the month and were sometimes bare.

A large majority of the observing stations in the southern half of England and in South Wales came through March without either snow or sleet. Among the very few places to report more than a sprinkling on the ground at any time was Princetown, where a 2 in. cover remained on the morning of the 1st from sharp snow showers of February 28 th.

\section{APRIL I950}

This wet and windy month, described by some observers as the roughest and coldest of the 1949-50 winter, greatly outdid March for frequency and intensity of snowfall over Britain as a whole, and distinguished itself by bringing to south-eastern England, on the night of the 25th-26th, the most severe snowstorm experienced in that part of the country so late in the season since I9rg. A majority of the days during the first three weeks of the month produced more or less snow in one or another upland northern district, and substantial cover to well below rooo ft. was not uncommon in Scotland, North Wales and northern England, particularly from about the 9th to 17 th.

A milder period followed from the 18 th to $22 n d$, but on the $22 n d-23 r d$ a depression east of Greenland moved south-eastward to the southern North Sea and in its rear an arctic air-stream became established over the British Isles, giving widespread and locally rather heavy snowfall. Depths of 5 in. to 6 in. were reported below ${ }_{5} 500 \mathrm{ft}$. in Denbighshire early on the $25 \mathrm{th}$. During the night of the 25th-26th a secondary disturbance which had formed in polar air near the Bristol Channel passed south-eastward and later eastward, reaching the Isle of Wight by midnight and the Dover Straits by o6.00 hr. on the 26th. Five to seven hours of continuous snow resulted over an irregular belt extending from north Kent across Surrey, north Hampshire, south Berkshire and Wiltshire. In some of these areas most of the snow melted as it fell, but this did not happen inland in the south-eastern counties, where the temperature was near freezing point. By sunrise on the 26 th the cover was commonly 5 in. to 8 in. deep on low ground and at least 10 in. to 12 in. deep along a stretch of the North Downs to southward of London. In the neighbourhood of Coulsdon, Surrey, an average depth of as much as 18 in. was reported by casual but independent and seemingly reliable observers to have occurred for a short time in the early morning. Yet in the northern outskirts of London there was a mere sprinkling, while 20 miles farther north, in south-east Buckinghamshire and south-west Hertfordshire, the whole night was clear and frosty.

Great destruction was caused by this storm. From Kent across Surrey and the southern London suburbs to Hampshire and Berkshire 37,800 telephone subscribers were cut off through the bearing down of the wires over a total length of some $6_{3}$ o miles and the breakage or falling of about 1230 poles. Serious impediment to rail and road traffic resulted throughout the forenoon. Thousands of fruit trees had their promise for the season ruined by the loss of main branches.

Away from south-eastern England substantial snowfalls during the night of the 25th-26th were chiefly confined to moderate and high levels in Wales; on the Brecon Beacons there was a layer 8 in. deep below $2500 \mathrm{ft}$. and 6 in. deep below $1000 \mathrm{ft}$. early on the $26 \mathrm{th}$.

The cold spell continued until the 28 th, with further local snow, but the month ended in warm weather, there being rapid melting of the cover in the Scottish Highlands on the 29th-30th.

At low and moderate levels the reported frequency of days with falls of snow or sleet reached a maximum of 14 at Achnashellach, Ross and Cromarty, while the greatest number of mornings with "snow lying" was 5 at Dalwhinnie, Inverness-shire, and Bwlchgwyn, Denbighshire. 
MaY $195^{\circ}$

Snowfall during this month of changeable but predominantly dry weather appears to have been confined to Scotland, where it occurred here and there from time to time (on 4 days at Dalwhinnie and 3 days at Braes of Glen Livet), mostly in the form of passing showers. On the Scottish mountains cover did not in general extend to below $2500 \mathrm{ft}$., though it was reported at between $\mathrm{I}_{5} 00 \mathrm{ft}$. and $2000 \mathrm{ft}$. on the Ben Wyvis group from the 18th to 20 th and below $1000 \mathrm{ft}$. on the Fannich Hills on the 19th.

\section{SUMMER I950}

June was a decidedly warm month on the whole, with a general mean temperature exceeding the normal by $4^{\circ} \mathrm{F} .\left(2 \cdot 2^{\circ} \mathrm{C}\right.$.) in England and Wales and by about $3^{\circ} \mathrm{F} .\left(\mathrm{r} \cdot 7^{\circ} \mathrm{C}\right.$.) in Scotland. There were, however, a few short-lived incursions of Arctic air over the northern half of Britain, and during these some local snow occurred at levels above rooo ft. Dalwhinnie, Inverness-shire, reported light falls on two days.

We are again indebted to the courtesy of the Durham University Exploration Society for a summary of snow studies undertaken by a party of its members who spent about three weeks of July in the upper Cairngorms. A large number of extensive snow beds were found at altitudes above $2700 \mathrm{ft}$., particularly in the Ben Macdhui, Monadh Mòr and Beinn a' Bhùird areas. On the higher northern and eastern slopes of Ben Macdhui (4296 ft.) surviving separate accumulations appear to have been much more numerous and generally deeper in mid-July I $95^{\circ}$ than at the same period of 1949 . Several of the major patches surveyed had an average depth of $4 \mathrm{ft}$. to $5 \mathrm{ft}$. One of these, on a steep incline to north-west above Loch Etchachan, was of horseshoe shape, measuring $60 \mathrm{yd}$. $(55 \mathrm{~m}$.) from east to west and $24 \mathrm{yd}$. $(22 \mathrm{~m}$.) from north to south at noon on fuly $27 \mathrm{th}$; at its inner northern margin it contained an ice-cave, presumably cut by a stream of under-running water. The snow was of the order of $3 \mathrm{ft}$. to $4 \mathrm{ft}$. deep along the arms of the horsehoe and $6 \mathrm{ft}$. to $7 \mathrm{ft}$. deep in their region of juncture. Two elongated banks of snow occupying very steep slopes in the Glen Avon valley were identified as the remains of cornices; on the evening of fuly 27 th the larger member of this pair, facing north-east, had a major axis $117 \mathrm{yd}$. (107 m.) in length, while the smaller, facing east, was $8 \mathrm{ft}$. deep near its lower edge.

From fuly 24th to 29 th the party took measurements of ablation in an extensive snow patch situated a short distance south-west of Loch Etchachan. Poles introduced at seven points showed that the mean depth of the snow decreased (any settling included) by $2 \mathrm{I} \cdot 5 \mathrm{in}$. in the course of the five days. During the night of $f u l y$ 27th-28th minimum temperatures of $32 \cdot 6^{\circ} \mathrm{F}$. $\left(0 \cdot 3^{\circ} \mathrm{C}\right.$.) and $27.5^{\circ} \mathrm{F}$. $\left(-2 \cdot 5^{\circ} \mathrm{C}\right.$. $)$ in the screen and on the ground respectively were registered at the party's base station in Glen Derry. Between $17.30 \mathrm{hr}$. on fuly 27 th and $09.40 \mathrm{hr}$. on Fuly 28 th ablation (plus any settling) in the snow patch under observation amounted to $\mathrm{I}_{5} \mathrm{~h}$ in. From $09.40 \mathrm{hr}$. on fuly 28 th to $12.00 \mathrm{hr}$. on $\mathcal{F u l y} 29$ th, which period included a night giving minimum temperatures of $43 \cdot 1^{\circ} \mathrm{F}$. $\left(6 \cdot \mathrm{I}^{\circ} \mathrm{C}\right.$.) in the screen and $40.9^{\circ} \mathrm{F}$. $\left(4 \cdot 9^{\circ} \mathrm{C}\right.$.) on the ground at the base camp, the mean decrement of snow depth in the patch just mentioned reached $7 \cdot 5$ in. Unfortunately no maximum thermometer was available.

A number of the snow beds studied by the party in mid-July had either dwindled markedly in area or disappeared entirely before the close of the month; but reports from the navigator of an aircraft which passed over the Cairngorms late in the third week of August have established that considerable accumulations of snow were then still to be seen here and there beneath the higher summits.

\section{SUMMARY}

Although on some of the northern mountains above $2000 \mathrm{ft}$. the aggregate duration of snow cover for the nine months September 1949 to May $195^{\circ}$ was greater than for any corresponding 
period since $1946-47$, as noted in a later section of this report, the season under review must be classed as one of light to moderate snowfall over Great Britain as a whole. Records from the ten selected representative stations at altitudes between $400 \mathrm{ft}$. and $1200 \mathrm{ft}$. (five in England, one in Wales and four in Scotland) that have been used for inter-seasonal comparison since the post-war re-institution of the Survey give an average of only 15 days with "snow lying" from September 1949 to May 1950. Over the same nine months the corresponding number was 66 in 1946-47, 26 in $1947-48$ and ${ }_{13}$ in $1948-49$.

It was for a few outstanding snowstorms, mostly of no very wide extent, rather than for general frequency or abundance of snowfall or for long duration of cover that the season achieved a modest measure of distinction. A noteworthy feature of the predominantly mild winter was the succession of falls during the first half of February which led to the blocking of upland roads in Scotland and northern England on several days and eventually produced accumulations ranging upwards in depth to an average of 36 in. at altitudes above $2000 \mathrm{ft}$. on the west Durham fells towards the middle of the month.

In early spring, March was snow-free to an exceptional degree at low and moderate levels, throughout the country. The snowstorm on the night of April 25th-26th in south-eastern England had not been rivalled at so late a date over this area since April 27th 1919, when a day-long fall deposited a cover 12 in. to 15 in. deep in the northern outskirts of London and adjoining districts of Hertfordshire and Buckinghamshire. The only other comparable late-April snowstorm of the twentieth century in southern England came on the 25th of the month in rgo8; on that occasion the average depth reached 18 in. or rather more locally in Berkshire, Hertfordshire and Oxfordshire and 16 in. as far south as the Isle of Wight.

The area of Great Britain that entirely escaped cover throughout the 1949-50 season was much smaller than in $194^{8}-49$, and complete freedom from snow or sleet appears to have been confined to the Scilly Isles and a few coast stations in the Devon-Cornwall peninsula.

E. L. H.

\section{NOTE ON DURATION OF SNOW COVER ON B R I T IS H M O U N T A I N S}

IT is to be regretted that observations from Elphin, Sutherland and Glen Livet, Banffshire, are no longer available. On the other hand, data have been received from the Paps of Jura (257 I ft.) for the 1949-50 season and from Ben Cruachan (3689 ft.), Argyllshire; Ben More (3169 ft.), Isle of Mull and the Harris Hills (Clisham, $2622 \mathrm{ft}$.), Outer Hebrides as from I December, 1949.

Although snowfall in the south was not remarkable for its frequency, the duration of snow cover on mountains above $2000 \mathrm{ft}$., particularly in Scotland, was this season the longest since the abnormally heavy snow season of $1946-47$.

Taking the same five representative mountains (two in Scotland, two in Wales and one in England), the average duration of snow cover at $2500 \mathrm{ft}$. was as follows : $1946-47,9 \mathrm{r}$ days ; $1947-48$, $57 ; 1948-49,41$; and $1949-5 \circ, 64$. The duration of snow cover was longest in December, February and April throughout the country. No snow was reported as lying at any level from any station during September, the first snow cover being observed from Glen Lyon on October 19th, when the snow line was down to about $3300 \mathrm{ft}$.; on the $21 \mathrm{st}$ the snow line was down to $2000 \mathrm{ft}$. on the Cuillins and to $2500 \mathrm{ft}$. in Glen Lyon and on Ben More, Isle of Mull.

Diagrams showing the distribution of snow cover relative to height for ten stations are given on pages 523 and 524 on the basis set out on p. 131 of the 1946-47 Report (Vol. 1, No. 3, 1948). 